\title{
DE LEVENDES LAND
}

\section{Af Peter Skautrup.}

Det er med nogen beklemmelse, jeg lader det følgende komme på tryk. Det kan måske være slemt nok mundtligt i universitetsøvelser at dissekere et litterært mesterværk sprogligt, men på tryk må det føles endnu mere ubarmhjertigt og småligt, ja rent ud sagt pernittengrynagtigt. Alligevel er der jo næsten ingen anden vej frem, om man vil prøve på at følge tilblivelsen og vurdere de sproglige virkemidler. Da må man igennem detaljen - og håbe på, at helheden og helhedsindtrykket ikke skal lide for megen skade derved. Det må da stå som et exempel på, hvorledes vi i en dansktime beskæftiger os med en nydansk tekst, som vi har mulighed for at følge i forskellige stadier, og det er måske ikke overflødigt at sige, at vi i en sådan gennemgang hverken kan give en litterært-æstetisk eller - her hvor det drejer sig om en salme - religiøs vurdering.

\section{Overleveringen.}

Digtet findes i forskellige affattelser.

I. Egenhændigt manuskript med egenhændige rettelser (de fleste tydeligt in scribendo). Grundtvig-ms. fasc. $388 \mathrm{nr} .91$ (fol. 251-252). Faksimile gengivet i Grundtvigs Sangværk. III (1948) som tillæg; endvidere i Grundtvig-Studier 1953 (mellem s. 56-57). - Tryk: J. Borup: Grundtvigs Stjerne. (1912). 110-113; Værker i Udvalg, ved Georg Christensen og Hal Koch. VIII. 1-3; (med udeladelse af flere af rettelserne bl. a. i) Poetiske Skrifter. V. 283-286 og Grundtvigs Sangværk. III. 145-148. - 13 strofer. - Tilblivelsesåret for denne digtets ældste form er ikke helt sikkert. Med Sv. Grundtvigs hånd er på manuskriptets første blad noteret (til højre:) »fundet ved prækener fra $23-25 \ll$ og (til venstre:) 》1824«. Denne datering er almindelig godtaget; herom nærmere ndf.

Anm. I fasc. $388 \mathrm{nr} .92$ findes et ufuldført udkast omfattende én strofe og begyndelsen til en anden:

1. [O deilige $>$ ] Velsignede Land

Hvor [Jord >] Blomst har ei Torne, og Tid ikke Tand, Hvor Rosen ei visner, og Fuglen ei døer, 
Hvor Lykken er klar, men ei skuffende skiør,

Hvor dyrt ikke kiøbes til Krone paa Baar

De sneehvide Haar!

\section{2. [Velsignede $>$ ] O deilige Land}

Som det vil ses af det følgende, synes denne tekst (ndf. citeret som II a) at forudsætte 1832-teksten (II).

II. Tryk: De Levendes Land. L. C. Hagen: Historiske Psalmer og Riim til Børne-Lærdom. 1832, nr. 67 (s. 197-203, som et af numrene $i$ et tillæg, der omfatter fire af Kingos morgen-, aften- og hjertesuk, Grundtvigs »De Levendes Land« og »hjertesukket《 »Søde Gud,

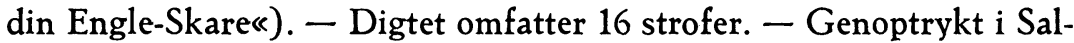
mer og aandelige Sange. IV. Kristen-Livet i Salme-Sang. (1875), nr. 214 (s. 319-322), Grundtvigs Sangværk. III. (1948), nr. 112 (s. 196199).

III. Tryk: Salmen »O Christelighed«, i Fest-Psalmer. 5. Oplag. (1853), nr. 740. -7 strofer. Optrykt i senere udgaver og salmebøger.

\section{Tilblivelsen.}

Ved dateringen af I henholder Rønning ${ }^{1}$ ) sig til Sv. Grundtvigs angivelse: 1824. Vilh. Andersen ${ }^{2}$ ) tænker sig, at digtet er blevet til efter eller under arbejdet med »Nyaars-Morgen«. Brix ${ }^{3}$ ) har formodet, at digtet er blevet til efter læsningen af 1 . del af Atterboms romantiske drama »Lycksalighetens O«, der udkom i sommeren 1824. Hertil har Johan Borup ${ }^{4}$ ) sluttet sig. Denne sammenstilling synes der ikke at være noget grundlag for. Sproglige reminiscenser har jeg ikke kunnet finde. Grundtvigs digt har jo også et ganske andet sigte end det at spille over et eventyrmotiv. Og det motiv, som skinner igennem her, er tydeligt nok Hadding-sagnet $\left.{ }^{5}\right)$. Det havde han i disse år jævnlig haft i tankerne, fra selve Saxo-oversættelsen, fra indledningsdigtet (senere kaldet:) 》Saxos Minde《 foran i 3. del af Saxo-oversættelsen 1822, og fra Nyaars-Morgen 1824, strofe $111 \mathrm{ff}$., hvor sagnet genfortælles (men med Grundtvig selv som hovedperson), og hvor ud-

1) Rønning: N. F. S. Grundtvig. III. 1 (1911). 42.

$\left.{ }^{2}\right)$ Illustr. da. Litteraturhistorie. III. (1924). 174.

3) Danmarks Digtere. 3. forøgede Udgave. (1951). $215 \mathrm{f}$.

4) N. F. S. Grundtvig (1944). 60 ff. Jf. også Steen Johansen: Bibliografi over N. F. S. Grundtvigs Skrifter. I. (1948). 283, hvor muligheden for 1825 som affattelsesåret drøftes.

5) Således også Uffe Hansen: Grundtvigs Salmedigtning. I. (1937). $94 \mathrm{f}$. 
trykket »de levendes Land« kommer igen gang på gang. Sidst har Kaj Thaning $i$ en grundig og interessant afhandling: Grundtvigs møde med Irenæus $\ll^{8}$ ) ment på grundlag af prædikener at kunne placere digtet i tidsrummet mellem to prædikener holdt henholdsvis 4 . søndag efter helligtrekonger $1 / 21824$ (prædikenens overskrift: Kiærlighed er Lovens Fylde) og 5. søndag efter helligtrekonger 8/2 1824 (overskrift: Kiærlighed er Fuldkommenheds Baand).

\section{Sproglig kommentar.}

Overskriften »De Levendes Land « findes først i II, men er anvendt i I (strofe 4 og 9 og den oprindelige tekst i strofe 14) side om side med deilige Land (str. 2 og 7) og Forjættede Land om gudsriget (eller »livets land« d.v.s. det land »Himmel og Jord, Hvor Kiærlighed boer «, jf. strofe 14). Allerede 1817 havde han brugt billedet i et ufuldendt digt Det ubekiendte Land $^{7}$ ), men her rigtignok med udgangspunkt $\mathrm{i}$ det oldgræske sagn om Faetons styrt i Eridanos (en myte Grundtvig flere gange har kredset om), så man ikke sikkert kan vide, hvordan tanken nærmere ville være blevet udformet. I adventsprædikenen ${ }^{30 / 11} 1823$ nævnes »de levendes Land $\ll^{8}$ ), i prædikenen 22. søndag efter trin. $\left({ }^{26 / 10}\right)$ »det forjættede, deilige Land«. - Udtrykket er primært gammeltestamentligt, brugt talrige steder (Job. 28.13, Ps. 27.13, 52.7, 69.29, 116.9, 142.6, Es. 38.11, 53.8, Ez. 26.20, $32.23 \mathrm{ff}$.) om denne verden, men det kunne jo let (jf. Joh. 11.25) overføres og bruges om paradiset (sml. vn. lifandi manna jorð . . bat er paradis eða sjalft himinriki), og således kan det op igennem tiden være brugt sporadisk, jf. et kaldsbrev ${ }^{30} / 11631^{\circ}$ ), hvori omtales en hr. Niels Andersen »huis Siæll Gud haffuer $i$ de leffuende Lander.

Metret er hentet fra Kingos salme »Far, Verden, far vel«, som også sprogligt kan spores.

Ved tekstgengivelsen i det følgende er rettelserne i I angivet på den måde, at den endelige tekst er trykt med bourgeois, mens den oprindelige tekst er trykt med petit (og tegnene $\langle$ og $>$ angiver henh. rettelse fra og rettelse til; iøvrigt henvises til faksimile i Grundtvig-Studier. 1953).

$\left.{ }^{6}\right)$ Grundtvig-Studier. 1953. 7 ff., spec. s. 56 og 60 . Prædikenerne findes i fasc. 16.

7) Grundtvigs Sangværk. III. (1948). $129 \mathrm{f}$.

8) Holger Begtrup. N. F. S. Grundtvigs kirkelige Syn 1825. (1901). 55. (Fasc. 16 , læg 1-2).

$\left.{ }^{9}\right)$ Hübertz. Aktstykker vedkommende Staden og Stiftet Aarhus. II. (1845). 59. 


\section{Strofe 1 .}

I. 1:

O deilige Land

$[<$ Jeg kiender et Land]

Hvor Haaret ei graaner og Tid har ei Tand

Hvor Solen ei brænder og [Blomsten ei døer >] Bølgen ei slaaer

Hvor Høsten [har $>$ ] omfavner den blomstrende Vaar,

Hvor Aften og Morgen gaae altid i Dands

Med Middagens Glands!

II. 1:

$$
\text { O, deilige Land, }
$$

Hvor Jord har ei Torne, og Tid har ei Tand,

Hvor Blomsten ei blegner, ei lægges paa Skaar,

Hvor Høsten omfavner den smilende Vaar,

Hvor Aften og Morgen, med Middagens Glands, Gaae altid i Dands!

Strofen mangler i III.

Rettelsen $O$ deilige Land er hentet fra str. 2; ved rettelsen fås parallele førstelinier i de første strofer. - Tid har ei Tand, alm. metafor (tilsvarende i ty. og eng.), Bording har: tidsens tand. - Blomsten ei døer; hvorfor opgivet? Har der ikke meldt sig et rimord? Rettelsen er foretaget in scribendo. - Hvor Aften og Morgen osv.; tiden eksisterer ikke; Johan Borup har i denne linie ment at finde en efterklang af et sted hos Atterbom (»hvar gårdag hvisker till hvar morgondag (). Dette synes meget søgt. Thaning ${ }^{10}$ ) henviser til et ældre sted hos Grundtvig (Verdenskrøniken. 1817. 622), men her er der tale om natten: »Natte-Vandringen i hine Timer, da Aften og Morgen synes at kysses med glødende Læber, som i en nordisk SommerNat«.

II. Hvor Jord har ei Torne. Man undrer sig over rettelsen: Det er jo ikke noget helhedsbillede! Er det Land, som drager Jord med, eller har Grundtvig ønsket lutter naturfænomener? - Hvor Blomsten ei blegner osv. Her genoptages det ældre billede i I, som G. vel altså har haft liggende foran sig netop i den overleverede skikkelse.

$$
\text { Strof e } 2 .
$$

I. 2:

Livsalige Land

$$
[<\text { O! deilige Land!] }
$$

Hvor Glasset ei rinder med [Taarer som Sand $>$ ] Graad eller Gran

Hvor Intet man savner som Ønske er værd

10) Grundtvig-Studier. 1953. 65. 
Hvor det ikkun fattes, som smertede her

Hvert Menneske søger med Længsel i Bryst

Din smilende Kyst!

II. 2 :

Livsalige Land,

Hvor Glasset ei rinder med Graad eller Grand,

Hvor Rosen ei falmer, og Fuglen ei døer,

Hvor Lykken er klar, men ei skinnende skjør,

Hvor dyrt ikke kjøbes til Krone paa Baar'

De snehvide Haar!

III.

Livsalige Land,

Hvor Glasset ei rinder med Graad eller Sand,

Hvor Blomsten ei visner, hvor Fuglen ei døer,

Hvor Lykken er skinnende klar, men ei skiør,

Hvor dyrt ikke kiøbes til Krone paa Baar

De snehvide Haar!

I. Taarer som Sand > Graad eller Gran; det første billede af timeglasset med tårer som sandskorn er jo udmærket, men man kan vel sige, at da denne verden jo dog ikke er karakteriseret udelukkende ved tårer eller gråd, så er modsætningen til paradiset eller gudsriget ikke så absolut ved blot at fremhæve tiden uden tårer, hvortil kommer at Grundtvig ved ændringen opnår allitteration, som næsten er et konstituerende drag i hans digtning. - Graad eller Gran, J: sorger og ubetydeligheder ( $\mathrm{J}$ : uden indhold eller værd); gran er et hyppigt brugt ord hos Gr., der synes at have udtalt det [gran'] Land.

I II en kraftig nyredaktion, helt ny tekst i strofens sidste 4 linier, og ubetinget en lykkelig ændring, fra det blege, abstrakte (med verberne som hovedord) til det billedrige, plastiske og farverige (med substantiver og adjektiver som hovedord). Det kasserede Blomsten ei døer i I. 1 fornyes, men gøres konkretere: Rosen ei falmer og Fuglen ei døer. - Lykken er klar, men ei skinnende skjør, tydelig reminiscens fra (Kingo og) Rimkrøniken (indl. til Regnar Lodbrog): Locken hwn maa wel lighnes et glar ** nar theth skyn alth som claræsth / tha brøster theth alth som snaræsth, jf. Peder Syv I. 287: Skinnendes Lykke gaar snart i Stykke; Lykken er af Glar; hun brister, naar hun skinner klar. - Hvor dyrt ikke kjøbes til Krone paa Baar' | De snehvide Haar! Der behøver ikke at ligge andet i udtrykket, end at ælde ofte er dyrekøbt her på jorden (jf. Kingo: Ach Ære, hvad er? / Hvad er dine Kroner og Krandse du bær?), men når man kender Grundtvigs tilbøjelighed til at forme sine billeder ud fra iagt- 
tagelse af konkrete detaljer, fristes man til at søge et tingsligt grundlag for denne metafor, selv om den måske kan synes stødende og plump. Har han kendt til en gammel skik at pynte liget med en hvid paryk? Og har en sådan eksisteret? Konservator Peter Linde har meddelt mig, at et lig fra Aarhus domkirke (nu i Nationalmuseet) var udstyret med en flosset paryk af blår, og at det samme iagttoges, da en kiste i kælderen under Marie Magdalene kirke blev åbnet (kistepladen bar navnet Beate Bylov +1659 , men kalotten på kraniet syntes at have tilhørt en mand; måske kan der være sket en forbytning, skriver Linde).

II a synes at forudsætte II. Er det en opskrift efter hukommelsen, med sammenblanding af strofe 1 og 2? Jf. varianten i lin. 4: skuffende skiør, som nok dækker tanken indholdsmæssigt, men verbaliter afviger fra kildestedet.

I III ændres lin. 3-4; Blomsten ej visner (jf. det kasserede i I.1 Blomsten ei døer) er måske indsat for at få parallellisme: Blomst - Fugl. - Lykken er skinnende klar er billedligt bedre, men til gengæld er men ei skiør som led betragtet poetisk mat og magert.

\section{Strofe 3 .}

I. 3:

Forjættede Land!

Du hilses i Morgenens speilklare Strand,

Naar Barnet [der $>$ ] mon skue din [Skygge

[Og drømmer, du findes hvor Jorden er grøn $>$ ]

fuldskiøn $>$ ] Lignelse skiøn,

Og drømmer, du findes, hvor Skoven er grøn

[Hvor Blomsten er yndig, hvor Himlen er blaa

Og Fuglene slaae $>$ ]

Hvor Barnet kan dele med Blomster og Siv

Sit Smil og sit Liv!

II. 3:

$$
\text { Forjættede Land! }
$$

Du hilses i Morgenens speilklare Strand,

Naar Børnene skimte din Lignelse skjøn,

Og drømme, du findes hvor Skoven er grøn,

Hvor Barnet kan dele med Blomst og med Siv Sin Lyst og sit Liv!

Strofen mangler i III.

I I adskillige rettelser. - Forjættede Land ville man tro var bibelsk, men det har ikke haft nogen større udbredelse i bibelsproget, ja har endog været fjernet fra bibelen i flere århundreder. Det findes ét 
sted i Chr. II's Ny Test., nemlig i Hebr. 11.9, hvor det siges om Abraham, at han boede i thet foriette land. Samme tekst har Chr. Pedersen og Christian III, men Resen (1607) retter til: $i$ Forjettelsens Land, og denne tekst bevaredes i de autoriserede tekster helt til 1948, der igen indførte det forjættede land, som dog findes hos Lindberg. Primært er det brugt om Kanaans land, Palæstina, det land som for Moses flød »med mælk og honning (jf. sv. det förlovade landet, fransk la terre promise; gr. gẽ tẽe èpaggelias, løftets land); i videre anvendelse så om det løfterige, lykkelige land; her = de levendes land. - speilklare Strand; billedet fastholdes fra strofe 2 (smilende Kyst), og det bevares i II. 3 skønt kystbilledet er opgivet $\mathrm{i}$ II. 2. Grundtvig kan altså ikke fastholde det oprindelige associationsforløb. - Rettelsen din Skygge fuldskiøn > din Lignelse skiøn er ikke foretaget in scribendo og må altså stamme fra tiden mellem 1824 og 1832; når Grundtvig retter her, er det vel for at undgå Skygge, thi for barnet er det ikke en skygge, men en afbildning eller spejling; valget af det trestavelses Lignelse tvinger da igen til rettelsen fuldskiøn > skiøn. - Linie 3 er rettet in scribendo (Jorden > Skoven). - Rettelsen af de to sidste linier synes efter blak og ductus også at være senere end 1824; man kan vel sige, at et vagt udtryk Hvor Blomsten er Yndig og et par traditionelle hvor Himlen er blaa / Og Fuglene slaae er udskiftet med et enkelt, simplere og mindre traditionelt (fra det foregående fastholdt) billede af det legende barn imellem blomster og sivplanter.

II. Den arkaiserende omskrivning for præsens Barnet mon skue opgives, hvad der igen kræver et trestavelses subjekt, altså $>$ Bornene skimter; børnene ser eller skuer ikke den hele afbildning, de skimter eller aner den $\mathrm{Og}$ drommer (lin. 4) som det nu engang er et særkende for børn (jf. salmen »Velkommen igen, Guds Engle smaa《, som Grundtvig fremsagde efter prædiken julemorgen 1825 i Vor Frelsers kirke, str. 4: Saa drømme de sødt om Bethlehem **De drommer: de lege Juul med dem $* *$ ).

\section{Strofe 4.}

I. 4:

O! flygtige Drøm!

Om Evigheds-Øen i Tidernes Strøm,

Om Templet for Glæden i Taarernes Dal

Om Halvgude-Livet i [Døndinge >] Dødninge-Sal, Med dig fra de Fleste henfarer paa Stand

De Levendes Land! 
II. 4 :

O, flygtige Drøm,

Om Evigheds-Øen i Tidernes Strøm,

Om Glædens Guld-Tempel i Taarernes Dal,

Om Halvgude-Livet i Dødninge-Sal,

Med dig fra de Fleste henfarer paa Stand

De Levendes Land!

Strofen mangler i III.

I. Kun en enkelt rettelse: Dondinge $>$ Dodninge. - HalvgudeLivet; (»halvgud« om det blandt guder optagne menneske); her om livet $\mathrm{i}$ de levendes land. - Taarernes Dal, efter Psalme 84.7 (Vulgata: in valle lacrymarum), der dog i danske autoriserede bibeloversættelser aldrig er oversat således (i Chr. III.: den Jammerlige dal; fra Resen og fremefter: morbær-dalen, 1931: Bakadalen); Lindberg har optaget Taare-Dalen (også i svensk bibel: Tåredalen). - Altså følgende paralleller:

$$
\text { Drømmen }\left\{\begin{array}{cl}
i & \text { Tidernes Strøm } \\
i & \text { Taarernes Dal } \\
i & \text { Dodninge-Sal } \\
\text { (ग: jorderiget) }
\end{array}\right\} \text { om }\left\{\begin{array}{l}
\text { Evigheds-Øen } \\
\text { Templet for Glæden } \\
\text { Halvgude-Livet }
\end{array}\right.
$$

Med dig ১: med den flygtige drøm farer »de levendes land« bort. II. Her rettes Templet for Glæden til det vægtigere og farverigere Glædens Guld-Tempel (et af de mange eksempler hos Grundtvig på anvendelse af typen 431 i skifte $>\smile-\smile$, her endda nærmest til 141); videre opnås allitteration.

\section{Strofe 5 .}

I.5: $[\mathrm{O}$ skuffende $>$ ] [Fortryllende $>$ ] O, skuffende Drøm Du skinnende Boble paa Tidernes Strøm, Forgiæves dig Skjalden, med Mund og med Pen Af glimrende Skygger vil skabe igien, Naar Skyggen er ligest, da hulke de Smaa Som stirre derpaa!

II. 5:

Skalkagtige Drøm!

Du skinnende Boble paa Tidernes Strøm, Forgjæves dig Skjalden med Mund og med Pen, Af glimrende Skygger vil skabe igjen;

Naar Skyggen er ligest, da hulke de Smaae, Som stirre derpaa! 
Strofen mangler i III.

I. Grundtvig har vaklet i første linie mellem $O$ skuffende, som først $>$ Fortryllende og derefter igen $>O$, skuffende. Den første rettelse kommer måske, da han begynder på næste strofe: Fortryllende Drøm / Som gixkker **, og så har det et øjeblik knebet for ham at komme videre. Han tænker da på at føre udtrykket op i strofe 5 og retter her, men så kommer ånden igen over ham til en ny strofe 6, og rettelsen her (strofe 5) annulleres. - Genklangen fra Kingo er tydelig; Far Verden far vel strofe 2:

Hvad er det dog alt

Som Verden opsminker med fauer Gestalt?

Det er jo kun Skygger og skinnende Glar,

Det er jo kun Bobler og skrattende Kar,

Det er jo kun Ise-skrog, Skarn og Fortred,

Forfængelighed,

Forfængelighed.

Drømmen skuffer, og skjalden ( $\supset$ : romantikeren) søger forgæves at genskabe dette land i sin digtning ( $\supset$ : skyggerne). Selv hvor denne digtning (Skyggen) ligner allermest (er ligest), er det jo kun en indbildning, over hvis tomhed og uvirkelighed vi må hulke.

II. Linie 1 rettes til Skalkagtige Drøm; drømmen er ikke blot skuffende, hvilket alene behøver at rumme en subjektiv vurdering, den er simpelthen skalkagtig, dvs. falsk.

$$
\text { Strofe } 6 .
$$

I.6: [Fortryllende Drøm

Som gixkker $>$ ]

Fortryllende Drøm

Om Evigheds-Perlen i Tidernes Strøm,

Du giækker [vort Øie $>$ ] de Arme, [som $>$ ] der [søger $>$ ]

søge om sonst

Hvad Hjertet begiærer, i Billed og Konst

Saa varigst [vi $>$ ] de kalde hvad sikkert forgaaer

Som Timer og Aar!

II. 6:

Fortryllende Drøm,

Om Evigheds-Perlen i Tidernes Strøm,

$\mathrm{Du}$ gjakker de Arme, der søge omsonst,

Hvad Hjertet begjærer, at skabe med Konst,

Saa varigt de kalde, hvad sikkert forgaaer

Som Timer og Aar! 
Strofen mangler i III.

I. Grundtvig har ikke kunnet få form på tankerne til at begynde med. Han har villet afslutte denne del af digtet med endnu en den tredje - strofe om drømmen. Han har syntes, at han ikke tilstrækkelig stærkt har understreget, at kunsten, den bildende og digteriske, kun er et blændværk, Som giækker, og som er dømt til forgængelighed. - Rettelsen i lin. 3 er oprindelig kun som > der; efter nedskriften af hele strofen eller senere rettes vort Øie $>$ de Arme, hvilket medfører søger $>$ søge og lin. 5 vi $>$ de.

I II kun en enkelt ændring, i lin. 4. $i$ Billed og Konst $>$ at skabe med Konst.

Herefter følger det nye afsnit om det evige livs væsen.

$$
\text { Strofe } 7 .
$$

\section{I.7: $\quad$ O, Kiærligheds Aand!}

Lad barnlig mig kysse din straalende Haand Som rækker fra Himlen til Jorderigs Muld Og rører vort Øie med Fingre som Guld, Saa blaalig sig hæver bag buldrende Strand [Det [de $>\div$ ] hellige Land $>$ ] Det deilige Land!

II.7: $\quad$ O, Kjærligheds Aand! Lad barnlig mig kysse din straalende Haand, Som rækker fra Himlen til Jorderigs Muld, Og rører vort Øie, med Fingre som Guld, Saa blaalig sig hæver, bag buldrende Strand, Det deilige Land!

III.7: O Kiærligheds Aand, Det evige Liv i Fuldkommenheds Baand!

O smelt du vort Hjerte ved Høialtrets Ild, Og klar du Jordklimpen i Solglandsen mild, Saa glade vi føle, os skabes i Bryst

De Levendes Lyst!

I. I manuskriptet er kun rettet i sidste linie. Oprindelig har han begyndt Det de-, men stryger de- og fortsætter hellige Land, hvorpå hele linien overstreges og $>$ Det deilige Land. - Kiærligheds Aand, dvs. Helligånden, karakteriseret ved kærligheden. Helligåndens hånd rører med sine fingre (jf. det bibelske »Guds finger«) vort øje, så det ser landet (opr. altså »det hellige land«), paradiset ${ }^{11}$ ). - Saa blaa-

11) Jf. her og i det flg. Toldberg: Grundtvigs symbolverden. (1950). $114 \mathrm{ff}$. 
lig sig hæver bag buldrende Strand; synet har skiftet karakter. Billedet kommer igen i str. 9: Der Isgangen trodser $i$ buldrende Strand. Landet ligger nu ikke længere med en smilende Kyst (str. 2) og den speilklare Strand, det ligger nu bag et hav (str. 10) i bevægelse, bag en brænding, der buldrer. Kan det være hentet fra Jeremias 51.16 (spådommen om straffen mod Babel): Naar hand udgiver røsten, er der et bulder af vande $i$ himmelen (Chr. VI)?

I II røres ikke ved teksten.

III. Strofen er helt omskrevet i salmen (1853), hvor den er sidste strofe. - Det evige Liv i Fuldkommenheds Baand, er taget fra Colossenserne 3.14: Men over alle disse ting ifører eder kierligheden, som er fuldkommenheds baand (Chr. VI), d.v.s. det evige liv er kærlighed; jf. prædikenen 5. s. e. helligtrekonger 1824 (Fasc. 16). - O smelt du vort Hjerte ved Hoialtrets Ild; billedet 》hjertet smeltes« ret alm. i bibelen (fx. Esaias 13.7, 19,1, Ezechiel 21.7); (Høi)altrets Ild, fra det gammeltestamentlige miljø, med offerilden på altret, d.v.s. i vor religiøse hengivelse. - Og klar du Jordklimpen $i$ Solglandsen mild; ordet Jordklimp bruger Grundtvig talrige steder ${ }^{12}$ ), og glosen synes at vise, at han har kendt eller benyttet Chr. III.'s bibel, der i 1. Mos. 2.7 har: Oc Gud Herren giorde Mennisken aff en Jordklimp. Han kan dog også have mødt ordet i ældre poesi, hvor det bruges om det forkrænkelige menneske ( $\mathrm{fx}$. hos Stub og Oehlenschläger). Endelig kan han (som Paludan-Müller tænker sig det) have kendt ordet fra (syddanske) dialekter, hvor det anvendes om en rå, kold og våd jordklump. Ved redaktionen af salmen er billedet vel hentet fra strofe 16: Klimpen af Jorden. - Og klar du Jordklimpen, d.v.s. du skal rense, lutre os.

Strofe 8 .

I. 8: $\quad$ O himmelske Navn!

Som aabner for vores din hellige Favn, Saa Aanden, usmittet, kan røre ved Støv,

Og levendegiøre det visnede Løv,

O lad mig [knæle $>$ ] nedknæle saa dybt i mit Leer,

At Gud mig kun seer!

II.8. O, himmelske $\mathrm{Navn}$,

Som aabner for vores din hellige Favn,

Saa Aanden, usmittet, kan røre ved Støv,

Saa grønnes kan atter det visnede Løv,

For dig vil jeg knæle saa dybt i mit Leer,

At Gud mig kun seer!

${ }^{12)}$ F. Paludan-Müller i Danske Studier 1945. 148-150. 
Strofen mangler i III.

I I kun en af metret krævet rettelse knæle > nedknæle. - Som aabner for vores, d.v.s. for vort navn, for os. - Lin. 3: så der kan skabes kontakt mellem det syndige (smitsomme) støv og ånden.

II. En vinding er ændringen Og levendegiore $>$ Saa gronnes kan atter; det abstrakte bogsprogsudtryk udskiftes med poetisk konkret. - Ved ændringen $O$ lad mig nedknæle $>$ For dig vil jeg knæle undgås et rytmeskifte i nedknæle.

\section{Strofe 9 .}

Strofen om dåben findes kun i II.

II.9:

O, Klippe-Elv god,

Som raader paa Helsot vidunderlig Bod,

Saa Dødningen dukker, og stiger paa Stand,

Gjenfødt til at boe i de Levendes Land;

Hver Tanke mig fødes, et aandeligt Liig,

Jeg døbe i Dig!

Klippe-Elv, om dåbens bad. - Helsot, (arkais.) døden; også tidligere brugt af Grundtvig. - Dødningen, om det jordisk-bundne, udøbte og derfor fortabte menneske. - Hver Tanke etc.; hver tanke jeg tænker, er død, uden varighed, uden liv, men døbt eviggøres den.

I.9:

$$
\text { Strofe } 10 .
$$

O, Vidunder Tro!

Som slaaer over Dybet den hvælvede Bro, [Fra Dødninge-Hjem til de Levendes Land [Som Iis-Gangen trodser $>$ ] Som Iis-Bjerge flytter $>$ ]

Der Iis-Gangen trodser i buldrende Strand Fra Dødninge-Hjem til de Levendes Land, [Boe >] Sid lavere hos mig, du Høibaarne Giæst! Det huger dig bedst!

II. 10:

$$
\text { O, Vidunder-Tro, }
$$

Som slaaer over Dybet den hvælvede Bro, Der lisgangen trodser i buldrende Strand, Fra Dødninge-Hjem til de Levendes Land;

Bo lavere hos mig, du hribaarne Gjæst, Det huger dig bedst! 
III. 4:

O Vidunder-T ro!

Du slaaer over Dybet din gyngende Bro, Som Iisgangen trodser i brusende Strand, Fra Dødninge-Hjem til de Levendes Land, Boe lavere hos os, det huger dig bedst, Du høibaarne Giæst.

I. Ved linie 3 har han haft billedet af Iis-Gangen og glosen Dødninge-Hjem (jf. str. 4 Dødninge-Sal). Rettelserne in scribendo forklarer i øvrigt sig selv. - Broen trodser isgangen langs den buldrende Strand (jf. ovenfor str. 7). - Boe lavere > Sid lavere; »i det lave« alm. bibelsk-religiøst om jordelivet, jorden. - Høibaarne, egentlig fra titulaturlisten (om fyrstelige og højadelige personer); herfra har Grundtvig vistnok hentet det ind i det poetiske sprog. - Det huger dig bedst; huge, formen alm. hos Grundtvig, brugt poetisk; egl. lidt frimodigt (man kunne snarere have ventet: det huer, d.v.s. behager, mig bedst!).

II. Den rettede tekst i I overtages næsten uændret.

III. I salmen ændres den hvælvede Bro > den gyngende Bro. Ligger der bag ændringen tanken om en vaklende tro ${ }^{13}$ ). - buldrende Strand $>$ brusende Strand - af lydlige grunde? Eller fordi det auditive $\mathrm{i}$ billedet ved revisionen er trådt $\mathrm{i}$ baggrunden? - hos mig $>$ hos os; digtet er nu en salme for menigheden.

$$
\text { Strofe } 11 \text {. }
$$

I. 10:

\section{Letvingede Haab!}

Gudbroder! gienfødt i den hellige Daab! For Reiserne mange til Landet bag Hav, For Tidender gode, for Trøsten du gav, Lad saa mig dig takke, at Glæde jeg seer Naar Haab er ei meer!

II. 11:

Letvingede $\mathrm{H}$ a a b,

Gudbroder, gjenfødt i den hellige Daab! For Reiserne mange til Landet bag Hav, For Tidender gode, for Ring og for Stav, Lad saa mig dig takke, at Glæde jeg seer,

Naar Haab er ei meer!

13) Således opfatter Uffe Hansen det (Grundtvigs Salmedigtning. I. (1937). 100. 
III. 5:

\section{Letvingede $\mathrm{Ha} \mathrm{ab}$ !}

Gudbroder, nyfødt i den hellige Daab!

O laan os den Fjederham, Aanden dig gav!

Saa tit vi kan flyve til Landet bag Hav,

Hvor Evigheds Soel skinner klart allenstund Paa Saligheds Grund!

I. Letvingede Haab! Gudbroder!; Jesus (vort håb) er i dåben blevet menneskets broder, en »gudbroder«. - For Reiserne mange etc.; Toldberg ${ }^{14}$ ) vil mene, at der hermed sigtes til »de fantasiridt, Grundtvig som Hading har foretaget paa Sleipner«. Det kunne vel også være et billedligt udtryk for hans gudstjenester. Jf. nedenfor. - For Tidender gode, for Trøsten du gav; om Thanings datering kan fastholdes, kunne ordene være udtryk for den »dagning«, den klaring og fortrøstning til fremtiden, som han i adventstiden 1823 nåede til i en opstemthedsperiode.

II. Endringen for Trosten du gav > for Ring og for Stav må vist tolkes således: I maj 1826 havde Grundtvig nedlagt sit præsteembede. I marts 1832 fik han Frederiks tyske kirke overladt til aftensangsgudstjeneste (men måtte hverken døbe eller forrette altergang). Ring og stav var bispens værdighedstegn (i den katolske tid). At Grundtvig nu takker for Ring og for Stav, er vel da udtryk for at han (igen) er Guds tjener.

III. Salmen er helt omskrevet. O laan os den Fjederham etc. Her er det i al fald ikke Sleipner, Grundtvig har tænkt på, men fjederhammen - den velkendte fra folkevisen og folkeeventyret - , som bringer ham over. Det er vel optakten Letvingede (Haab) (letvinget synes ikke tidligere hjemlet $\mathrm{i}$ dansk), der har bragt ham til det nye billede. - De sidste to linier temmelig tomme, udfyldende og banale.

\section{Strofe 12.}

I. 11:

O, Kiærlighed selv!

Du rolige Kilde for Kræfternes Elv

Han kalder dig Fader, som løser vort Baand,

[Og levende Sjale $>$ ]

[Hver >] Al Livs-Kraft i Sjælen er Gnist af din Aand

Dit Rige er der hvor [Død bydes $>$ ] man Død byder Trods, Det komme til os!

14) Grundtvigs symbolverden. (1950). 201. 
II. 12:

$\mathrm{O}, \mathrm{Kj}$ ær $\mathrm{lighed} \mathrm{Selv}$,

$\mathrm{Du}$ rolige Kilde for Kræfternes Elv!

$\mathrm{H}$ a $\mathrm{n}$ kalder dig Fader, som løser vort Baand,

Al Livs-Kraft i Sjælen er Vift af din Aand,

Dit Rige er der, hvor kun Død finder Trods:

Det komme til os!

III. 6:

O Kiærlighed selv,

Du rolige Kilde for Kræfternes Elv!

Du fylder med Frelserens gavmilde Ord

Velsignelsens Kalk paa det christne Gudsbord;

O vær du vor Livdrik paa Jorden og bliv

Vort evige Liv!

I. Kiærligheden selv, d.v.s. Gud (jf. de mange steder i Johannesbrevene, hvor Gud kaldes kærlighed, jf. 1. Joh. 4.8, 4.16). - Du rolige Kilde, jf. Jeremias 17.13: Herren, de levende vandes kilde. - Han * * som loser vort Baand, d.v. s. Jesus - [Og levende Sjæle $]$ - her har han ikke kunnet komme videre; med tanke på forløsningen og opstandelsen kan det være 1. Cor. 15.45, som har meldt sig: det forste menniske, Adam, er blevet til en levende siel; den sidste Adam til en levende-giørende Aand (jf. 1. Mos. 2.7).

II. Endringen i lin. 4 Gnist $>V$ ift, i nærmere tilknytning til 1. Mos. 2.7: Og Gud Herren havde dannet mennisket af stov, af jorden, og blæst lives aande $i$ hans næse; og mennisket blev til en levende siel. - hvor kun Dod finder Trods, en meget søgt konstruktion; det naturlige udtryk er manuskriptets oprindelige hvor Dod bydes Trods; konstruktionen med man har han fundet upassende, hvor det drejer sig om Guds rige.

III. Salmen stærkt omdigtet. Her er det tydeligt nok Kilden, der er udgangspunkt for videreførelsen af et billede, nemlig alterkalken - med drikken, egl. Jesu blod, her Frelserens gavmilde Ord, der skal være vor Livdrik her på jorden.

\section{Strofe 13.}

I. 12:

Vor Fader saa huld!

[Som >] Du gierne vil throne i Templet af Muld,

[Som Sonnen har renset, og Aanden ombygt $>$ ]

Som Aanden opbygger i Midlerens Navn,

[Den rygende Tande dig kalder sin Bøn

Og selv du [optænder >] antænder det Lys udi Løn >] 
Med rygende Alter i Menneske-Favn,

[Og skaber en >] Med Himmellys-Bolig af Gnisten i Løn

Til dig og din Søn!

II. 13:

Vor Fader saa huld!

$\mathrm{Du}$ gjerne vil throne i Templet af Muld,

Som Aanden opbygger i Midlerens Navn,

Med rygende Alter i Menneske-Favn,

Med Himmellys-Bolig af Gnisten i Løn,

Til Dig og Din Søn!

Strofen mangler i III.

I. Gud 》vil gerne« dyrkes i »templer« her, som Helligånden opbygger i sønnens (Midlerens) navn (jf. den oprindelige, overstregede 2. linie). - De følgende to linier: Den rygende Tande ** Lys udi Lon må rettes, fordi han helt har glemt rimskemaet! Sidste linie og rimet udnyttes så til slut. - Den rygende Tande; det er vistnok Grundtvig, som indfører ordet Tande i bibelcitate ${ }^{15}$ ), der stammer fra Esaias 42.3; Chr. III, Resen og Chr. VI har: den rygende hor, først 1871oversættelsen har den rygende Tande; men Lindberg har det (vel sagtens fra Grundtvig): knækket Ror han ei vil bryde, rygende Tande han slukker. Grundtvig bruger citatet flere steder (fx. i digtet 》Herrens Ord《 fra 1826: Aldrig jeg knuser det knækkede Rør, | Slukker den rygende Tande $\left.{ }^{16}\right)$. - Rettelsen Og skaber en Bolig $>$ Med Himmellys-Bolig er en senere rettelse; det havde egl. været mere forståeligt, om han havde bevaret den oprindelige tekst.

II. Den rettede tekst i I optages uforandret.

$$
\text { Strofe } 14 .
$$

I. 13:

O Christelighed!

Du skiænker vort Hjerte hvad Verden ei veed, Hvad svagt vi kun skimte, mens Øiet er blaat,

Det lever dog i os, det føle vi godt,

[Vi elske, vi leve, vi kiende forsand De levendes Land $!>1$

(i margen:) [Sit >] Mit Land, [kalder $>$ ] siger Livet, er Himmel og Hvor Kiærlighed boer! Jord,

15) I prædikenen 5. s. e. helligtrekonger 1824: Han vil ingenlunde sønderbryde det knuste Rør eller slukke den rygende Tande.

16) Grundtvigs Sangværk. III. (1948). 159. - I Morten Larsens bøn efter prædiken hed det altid: Du har aldrig knust det brudte rør, du har aldrig slukket den rygende tande (udtalt: [ta'nə]). 
II. 14:

O, Christelighed!

Du skjænker vort Hjerte hvad Verden ei veed;

Hvad svagt vi kun skimte, mens Øiet er blaat,

Det lever dog i os, det føle vi godt;

Mit Land, siger Livet, er Himmel og Jord, Hvor Kjærlighed boer!

III. 1:

O Christelighed!

Du skjænker vort Hjerte hvad Verden ei veed, Hvad svagt vi kun skimte, mens Øiet er blaat, Det lever dog i os, det føle vi godt;

Mit Land, siger Herren, er Himmel og Jord, Hvor Kiærlighed boer!

I. Christelighed, det at være kristen, tilhøre den kristne menighed; her personificeret. - mens Øiet er blaat, mens vi lever ${ }^{17}$ ). - De udstregede to linier har, så vidt jeg kan se, ingen kommenteret. De udtrykker vel, lidt dunkelt, at vi elsker og lever, d.v.s. »har andel i«, og kiende, d.v.s. føler - dette fællesskab i De levendes Land, hvormed han har ønsket at afrunde digtet. - Rettelsen af de to sidste linier - tilskrevet i margen - må høre den senere revision til, mens rettelsen i denne nye tekst Sit Land kalder Livet $>$ Mit Land, siger Livet, er foretaget in scribendo. Altså: hvor kærlighed bor, der hvad enten det er himmel eller jord - har livet hjemme, der er dets »de levendes land«.

II. Den rettede tekst i I optages uforandret.

III. Den eneste ændring i salmen, som indledes med denne strofe, er Mit Land, siger Livet $>$ Mit Land, siger Herren.

$\mathrm{Da}$ Grundtvig i 1832 giver Hagen digtet til offentliggørelse, har han ikke kunnet standse her, men føjer to vers til, der egentlig ikke bringer noget som helst nyt ind, men som er meget svagere og til dels gentagelser.

\section{Strofe 15 .}

II. 15:

Livsalige Drot,

Som græder for Hadet, og smiler ad Spot!

$\mathrm{O}$, vær $\mathrm{Du}$ vort Hoved, o, vær $\mathrm{Du}$ os Alt

Da vorde vi Kæmper i Dværge-Gestalt,

Da Guddommen lever, og bygger og boer

I Hytter af Jord!

17) Toldberg (Grundtvigs symbolverden. 115) vil yderligere lagge ind $\mathrm{i}$ udtrykket: afspejlingen af den blå himmel. 
Strofen mangler i III.

Livsalige Drot; »livsalig« betyder vel her »huldsalig, kær, elsket«. - Da vorde vi etc.; skønt dværge bliver vi i fællesskabet til kæmper.

\section{Strofe 16.}

II.16:
O, herlige Lodd.

At leve, hvor Døden har mistet sin Brodd,

Hvor Alt, hvad der blegned', skal blomstre paa $\mathrm{Ny}$,

Hvor Alt, hvad der segned', skal løftes i Sky,

Hvor Klimpen af Jorden: de Levendes Lyst,

Er Klippen i Bryst!

III. 2:

\section{Lyksalige Lodd,}

At leve hvor Døden har mistet sin Brodd,

Hvor alt hvad som blegned, opblomstrer paany,

Hvor alt hvad der segned, opfarer i Sky,

Hvor Kiærlighed voxer som Dagen i Vaar,

Med Roser i Haar!

II. At leve, d.v.s. i de levendes land. - hvor Døden har mistet sin Brodd; jf. 1. Kor. 15.55-56: Dod! hvor er din braad! helvede! hvor er din seyer? Men dodens braad er synden; men loven er syndens kraft. - Klimpen af Jorden, her om hjertet, der igen, som sæde for kærligheden, er de levendes lyst, der bliver en klippe i brystet; men temmelig tåget.

III. O, herlige Lodd > Lyksalige Lod; lyksalig, d.v.s. lykkelig, som gør lykkelig. - blegned - blomstre > blegned - opblomstre, og i næste linie skal loftes > opfarer; Grundtvig er - som så ofte - ikke ængstelig for metrisk skifte $(431>141)$. - De to sidste linier i II ændres 1853 til det lettere, men også lidt letkøbte billede af kærligheden, der vokser - med roser i hår - som dagen i vår.

Under tilblivelsen af I ser vi Grundtvig adskillige steder in scribendo foretage rettelser, men $\mathrm{i}$ det hele har tankepresset ikke haft vanskeligt ved at finde endeligt udtryk. Det er gået hurtigt, hvorfor han løber fast i enkelte linier (således i strofe 6,10,12 og 13), fordi helheden (tankebilledet og metriske krav eller rimkrav) ikke har formet sig færdigt, inden pennen tog fat. Mærkeligt er dog billedskiftet strofe 7. Har der været et ophold i skabelsesforløbet? 
Ved redaktionen af II har Grundtvig flere steder søgt at udbedre den oprindelige tekst, og enkelte rettelser i I kan måske netop stamme fra denne revision (således vel linie 1 i strofe 1 og 2, linie 2 i strofe 2, linie 5-6 i strofe 3, linie 5 i strofe 13 og linie 5-6 i strofe 14), men den således rettede tekst kan dog kun være et mellemled for 1832teksten, hvis renskrift eller trykmanuskript vi ikke kender. Han har tilføjet tre strofer, det ene (om dåben) efter I.8, de to andre til slut.

Ved salmekompositionen 1853 har Grundtvig gjort et heldigt valg af strofer:

$$
\text { I (1824) II (1832) }
$$

Strofe $1=$ str. 13 str. $14 \quad$ O Christelighed (næsten uændret).

$$
\begin{aligned}
& -2=\div \quad-16 \text { Lyksalige Lodd (ret omskrevet). } \\
& \text { - } 3 \text { =str. } 2 \text { - } 2 \text { Livsalige Land (ret uændret). } \\
& \text { - } 4=-9 \quad-10 \quad \text { O Vidunder-Tro (ret uændret). } \\
& -5=-10 \quad-11 \text { Letvingede Haab (ret omskrevet). } \\
& -6=-11-12 \quad \text { O Kiærlighed selv (ret omskrevet). } \\
& -7=-7-7 \text { O Kiærligheds Aand (helt omskrevet). }
\end{aligned}
$$

I denne tekst er kun 3 strofer overtaget nogenlunde uændret, 3 er ret stærkt omskrevet og én strofe er helt omarbejdet. Men i salmen skabes ved denne korte form en fast kombineret tekst, hvor aktualiteter, som ligger bag om adskillige udtryk i I og II er fjernet, og hvor jeg'et helt er fortrængt af vi og os, d.v. s. digtet er blevet menighedens salme. 